Published by European Centre for Research Training and Development UK (www.eajournals.org)

\title{
EMPLOYEE JOB SATISFACTION IN NIGERIAN TERTIARY INSTITUTION: A COMPARATIVE STUDY OF ACADEMIC STAFF IN PUBLIC AND PRIVATE UNIVERSITIES
}

\author{
Adenike Oluyemi Bello; Oluwaseun Mary Ogundipe \& Sunday C. Eze \\ Department of Business Admininstration \\ Landmark University, Omu-aran, Kwara State. \\ Email: bello.adenike@lmu.edu.ng
}

\begin{abstract}
The paper examines the difference that exists in the level of job satisfaction between academic staff in private and public tertiary institutions in Nigeria. Centred on detailed review of literature, the hypothesis formulated for research is whether academic staff in public universities are more satisfied with their jobs compared to academic staff in private universities. The variables with which job satisfaction was measured are recognition, pay and working condition. The sample of the study comprise 120 academic staff - 88 members of staff from a public university and 32 academic staff from a private university within Kwara state, Nigeria. Questionnaires were used as the instrument with which primary data was collected. Independent ' $t$ '" test was performed to obtain the difference in job satisfaction between both sectors of tertiary institution. Also, oral interviews were arbitrarily conducted with 8 academic staff from both universities. The findings of the research indicate that a significant difference in job satisfaction exists between academic staff in private and public universities in Nigeria. The result also showed the following: 1. Academic staff in private universities have better working conditions 2. Academic staff in public universities have better payment package 3. Academic staff in private universities are more recognised for their job. Recommendations were offered by researcher to cater for the short-falls identified from the dichotomy in job satisfaction from both sectors 1. private-public interaction 2.To enhance job satisfaction of academic staff in private universities, Government should formulate policies that will cater for other incentives, such as enjoyed by academic staff in public universities.
\end{abstract}

KEYWORDS: Academic staff, Private Universities, Public universities, Job satisfaction, Nigeria

\section{INTRODUCTION}

The development of any country is largely dependent on the rate of investment in education. Not just education, but institution of higher learning, that is tertiary education. The success of tertiary institution is dependent on the providers of knowledge. University education is fundamental to the construction of a knowledge economy and society at large (Anho, 2011). Therefore, it has become expedient that these providers or carrier of knowledge be well satisfied with their jobs. This is because success of the nation is a function of the students, 
and the success of the students is not independent of the knowledge providers, but has an undeniable effect on each other. The relevance of job satisfaction to both universities makes this research highly substantial. There are diverse factors in Private and Public Universities that can sway the performance of the employee, for example, job safety, salary, contingent reward, good working condition, relationship with co-workers, promotion, supervision, fringe benefits, good communication with other co-workers, and job nature can all influence the performance of staff in all institution. Employee bears "a positive view for his work responsibilities because of his level of job satisfaction". Moreover, employees have individual and professional concern with respect to their universities, including burden to trail excellence, to make the factual verdicts concerning the research schedule and course load, and guarantee balance between 'work life and family life'. As a result of job dissatisfaction of employee, their performance will be lessened and they will be incompetent to contribute to educational sector. For this reason, this study focuses on exploring the factors causing employee job satisfaction. The focus is to measure the job satisfaction between Landmark University lecturers and University of Ilorin lecturers.

\section{Historical background of University Education in Nigeria}

Prior to the emergence of private universities in Nigeria, the public universities had gained strong hold on the tertiary system of education in the Country. Various researchers traced the existence of Public universities to the colonial era. This was birthed out of dissatisfaction of few Nigerians who acquired higher level of education from foreign universities. (Okoro, PrisciEdwin, 2014) Universities were established as the only medium for achieving rapid and desired pattern of Economic growth. It is a place for training skilled manpower and also a means of developing human capital needed to sustain the economy.

Nigerian universities have three forms of ownership; federal, state and private. The federal and state are categorised as the public universities, while the privately owned are the private universities.

(Matthew, 2013) traced the advent of private participation in provision of university education to 1979 under the civilian government, when 26 private universities were established, but later scrapped under decree 19 of 1984. This was due to deregulation in quality of university education. Although the country had a large number of public universities, these universities could not cater for population of students who seek for admission on yearly basis into universities. Among the reasons for establishment of private universities as mentioned by (Matthew, 2013) were: Unsatisfied demand for admission into universities, limited and decaying infrastructural facilities, strikes, student unrest and cultism, negative attitudes of lecturers, low ranking of the universities, trend in global science and technology development and fall in quality of universities' graduates. These reasons birthed the establishment of the first 3 private universities (Babcock University, Madonna University and Igbinedion University) in 1999. Since then, universities in Nigeria have increased to 
about 143; 82 are publicly owned, while 61 are privately owned (National Universities Commission, (NUC) 2015).

The purpose of university education in Nigeria as stated in the policy of Education (2004) as to: (a) contribute to national development through high-level relevant manpower training (b) develop and inculcate proper values for the survival of individual and society (c) develop intellectual capacity of individuals to understand and appreciate their local and external environment (d) acquire both physical and intellectual skills which will enable individuals to be self-reliant and useful members of the society (e) promote and encourage scholarship and community service (f) forge and cement national unity (g) promote national and international understanding and interactions (Ajayi \& Ekundayo, 2008; Badmus \& Enahoro, 2013)

The mission of universities are to promote intellectual inquiry and to generate, store and transmit specialized knowledge and sophisticated expertise, higher forms of culture and ethical bases of conduct(Badmus \& Enahoro, 2013) and academic staff are key to the success of such mission (Amazt \& Idris, 2011)

\section{Statement of Problem}

In Universities, employee job satisfaction is assumed to play a substantial role in overall functioning of the institution. Satisfaction of academic staff is necessary for academic performance and consequently, for quality of university education (De Lourdes Machado, Soares, Brites, Ferreira, \& Gouveia, 2011) and for a university to get ahead there must be deliberate policy to integrate employee job satisfaction to improve worth and performance.

The drive of this research is to examine and compare the job satisfaction of lecturers in Landmark University and University of Ilorin and to explore any relationship existing between the job satisfaction elements and overall job satisfaction.

\section{Objectives of the Study}

Having established reasons for the existence of universities in the public and private sectors, it is important to understand if there is also a difference in employee satisfaction of both sectors. This will help identify ways to bridge the gap that may exist, so that the essence for university education can be achieved, regardless of the sector of existence. To this end, the broad objective of this paper is to identify the variance in the level of job satisfaction among academic staff in private and public universities in Nigeria. In doing this, the specific objectives are:

1. To investigate the extent to which Landmark University (LMU) lecturers differ from University of Ilorin (UNILORIN) lecturers in terms of pay.

2. To examine recognition among the Lecturers in Landmark University (LMU) and University of Ilorin (UNILORIN).

3. To identify the difference in the level of working condition between the employees of Landmark University (LMU) and University of Ilorin (UNILORIN) 
Global Journal of Human Resource Management

Vol.5, No.4, pp.33-46, May 2017

Published by European Centre for Research Training and Development UK (www.eajournals.org)

\section{Research Questions}

In order to give this research a focus and serve as a guild to the researcher, the following questions are adopted:

1. To what extent do lecturers of LMU and UNILORIN differ in terms of pay?

2. Is there any difference in recognition among the lecturers in LMU and UNILORIN?

3. Is there any difference in the level of working condition between the employees of LMU and UNILORIN?

\section{Research Hypotheses}

H1: There is no difference between lecturers at LMU and UNILORIN in terms of pay.

$\mathrm{H} 2$ : There is no difference in recognition among the lecturers in LMU and UNILORIN

H3: There is no relationship in the level of working condition between the lecturers of LMU and UNILORIN

\section{Significance of Study}

The significance of this study is rational hence the study is expected to serve as a measuring instrument for looking at problems of employees being job satisfied in relation to commitment. This study will inform Landmark University and University of Ilorin with the information entailed about the need of its employees

Results of this study will be of immense use to management of both universities. It will equally assist the management to understand how to properly encourage their lecturers to be more committed to work and be satisfied with their jobs. Thus the results of this study are significant in several ways.

Also, it is hoped that findings of the study will be of great Importance to target institutions i.e. LMU and UNILORIN.

In addition, the policy makers in universities under study may use findings of study to redress problems affecting their Job satisfaction, consolidate on their strong areas and improve on their weaknesses with a view to enhancing the commitment of employees.

The government policy-makers and other participants can utilize the findings of study to formulate and implement proper policies regulating employee job satisfaction of private universities and public universities in Nigeria.

Finally, the study will make a contribution to the existing theories on employee job satisfaction. The research work will provide insight for further research and broaden their knowledge of the tool or weapon (Employee job satisfaction). 
Published by European Centre for Research Training and Development UK (www.eajournals.org)

\section{LITERATURE REVIEW}

Satisfaction is a state of fulfilment. It is arrived at when one's desire meets up with what is available. Most times, when an employee is asked if he is satisfied with his job, what simply comes to mind is money, but research has shown that what one derives satisfaction from depends on what one is motivated by. (Demirtaş, 2010) was of the view that there are no universally accepted definitions of satisfaction. Also, (Akhtar, Hashmi, \& Naqvi, 2010) defined Job satisfaction as an effective or emotional response towards various facts of one's job. It can be an effect of satisfaction derived from various factors such as relationship with peers at work, supervisors, or family members. Such satisfaction can be derived from achievement at work or a mile stone that is crossed.

Herzberg and Peterson (1959) identified the following 6 factors for measuring job satisfaction; general satisfaction and moral, attitudes towards the company and its policies, satisfactions with intrinsic aspects of the job, attitudes towards immediate supervisor, attitudes towards satisfaction of aspirations and satisfaction with conditions of present job. (Akhtar et al., 2010) viewed job satisfaction from the perspective of a psychologist. To them, Job satisfaction examines the feelings of individuals. They are also of the view that the level of satisfaction an employee derives from a job is a function of both intrinsic and extrinsic motivating factors, the quality of supervision, social relationships with the work group and the degree to which employee succeeds or fails in given assignment.

Employee Job satisfaction is an essential facet of employees' work life. Job satisfaction does not only develop performance of the staff, it also influences other domain of their lives. Hackman \& Old man (1980) found that high job satisfaction is related with a higher level of increased output, lower absenteeism and lower employee turnover.

Job satisfaction has been described by Locke (1976) as a "pleasant or positive emotional state resulting from the assessment of one's job or job experiences". It is the collection of feelings that an individual grasps in the direction of their jobs (Robins 2005). Spector (1997) described Job satisfaction as a global feeling about job or as a related constellation of attitudes about various aspects or facets of the job. Job satisfaction is one of the most important factors that every job atmosphere which bring dynamic and successful ambience into every workplace across the globe (Jafar, Kavousian, Beigy, Emami, \& Hadavizadeh, 2010) identified 5 major aspects of job satisfaction as: satisfaction from job, satisfaction from supervisor, satisfaction from colleagues, satisfaction from salary and satisfaction from promotion. In addition, various researches has shown that academic staff derive satisfaction from factors such as developing warm and personal relationship with students, the intellectual challenge of teaching and autonomy (Amazt \& Idris, 2011) while dissatisfaction is traceable to workload, poor pay and low recognition. (De Lourdes Machado et al., 2011) linked job satisfaction with labour market behaviour, which is related to employee's attitudes. They also argued that employee job satisfaction affects their health and well-being. Luthan 2002 revealed three generally accepted dimensions of job satisfaction. Job satisfaction is an 
emotional response to a job condition. It is Job often determined by how well results meet or exceed expectations. For example, if workers feel that they are working much harder than others in the same institution, but are receiving fewer rewards, they will probably have a negative attitude towards the work. Job satisfaction represents various attitudes such as salary, opportunities for promotion, working conditions, co-workers, supervisor and the work nature

Other factors have been linked to have positive relationship with job satisfaction. (Aslan et al., 2014) identified positive relationship between Perceived Organisational Support (POS) and Leader-Member Exchange (LMX) with job satisfaction. POS is the level at which employees perceive the extent to which the organisation values their contributions and concerns about their well-being (Eisenberger, Huntington, Hutchison and Sowa, 1986). POS from the organisation leads to psychological and social bond between organisation and employees and influence their commitment to the organisation (Aslan et al., 2014) also, there is a string between job satisfaction and organisational citizenship behaviour (OCB). (Aslan et al., 2014) described OCB as a set of discretionary behaviours exhibited by employees that are not directly or clearly recognised by the formal reward system and positively impact their operation in the organization.

\section{THEORETICAL FRAMEWORK}

Various theories have been propounded on job satisfaction. (Adeniji, 2011) among other theories in her work identified Interactive theories of job satisfaction, Herzberg's two-factor theory and job characteristics model. Interactive theories of job satisfaction measured employee and condition he/ she find self. The theory is a combination of Cornell Integrative Model and Locke's Value-Percept theory. Cornell Model viewed job satisfaction as a function of steadiness between what individual puts in to job role (e.g. training, experience, time and effort), and role outcomes, that is what is received (e.g. pay, status, working conditions). Meaning, there is a connection between input invested and output received. Locke's Value-Percept Theory is of the view that the value an employee attaches to job or derives from job determines the rate of satisfaction derived from it. Herzberg's two-factor theory identified both motivating and hygiene factors. These factors are intrinsic in nature and are employee's responsibilities, achievement and job itself. The hygiene factors are the extrinsic factors and can lead to job dissatisfaction. They are company policies, working conditions and pay. Herzberg believed that for organization to get the best of employee, it should focus on the motivating factors. The last model is the four drive motivation model by Nohria, Groysberg and Lee (2008). The model states that employee motivation is influenced by complex system of managerial and organizational factors. The drivers are naturally built into humans, and the level to which they are satisfied will significantly impact the emotions of employees, thereby influencing their behaviour to work. The four drivers are treated independent of each other and cannot be substituted or placed in order of hierarchy. It consist drivers that motivates employees, levers that managers can pull to motivate and strategies to boost motivation. The drivers are the drive to acquire, drive to bond, drive to comprehend and drive to defend. Human being is naturally driven by the ability to acquire scarce resources; 
which ultimately boosts the sense of well-being. The drive to bond is associated with the strong positive emotion which brings a sense of belonging. When this is met, employees feel proud to belong to the organization which also motivates them to work. The drive to comprehend describes the desire to make meaningful contribution to the organization. That is, employees are motivated by jobs that challenge their reasoning, aid their growth and improve on their learning. Lastly is the drive to defend. It describes the desire of employees to fight for what they believe in. It is the desire to be a part of an institution that promotes justice, possess clear goals and intentions and allows people to express their ideas and opinions. When this desire is met, employees are secured and confident of the organization; which ultimately motivates employees to do more. In addition, the manager's levers are the reward systems, culture, job design and performance management and resource allocation processes. (Nohria et al., n.d.) The table below gives a description of the model.

\section{$\underline{\text { Table } 1}$}

\begin{tabular}{|c|c|c|}
\hline Drive & Primary Lever & Actions \\
\hline Acquire & Reward systems & $\begin{array}{l}\text { - Sharply differentiate good performers from } \\
\text { average and poor performers } \\
\text { - Tie rewards clearly to performance } \\
\text { - } \quad \text { Pay as well as your competitors }\end{array}$ \\
\hline Bond & Culture & $\begin{array}{l}\text { - Foster mutual reliance and friendship } \\
\text { among co-workers } \\
\text { - Value collaboration and teamwork } \\
\text { - Encourage sharing of best practices }\end{array}$ \\
\hline Comprehend & Job design & $\begin{array}{l}\text { - Design jobs that have distinct and } \\
\text { important roles in the organization } \\
\text { - Design jobs that are meaningful and foster } \\
\text { a sense of contribution to the organization }\end{array}$ \\
\hline Defend & $\begin{array}{ll}\text { Performance } & \\
\text { management } & \text { and } \\
\text { resource } & \text { allocation } \\
\text { processes } & \end{array}$ & $\begin{array}{l}\text { - Increase the transparency of all processes } \\
\text { - Emphasize their fairness } \\
\text { - Build trust by being just and transparent in } \\
\text { granting rewards, assignments, and other } \\
\text { forms of recognition }\end{array}$ \\
\hline
\end{tabular}


Based on various theories and conclusion from various researchers, one can describe an employee as one that exists in an environment. An environment is the summation of the surrounding one function in. It affects one's existence. This implies that each academic staff exists in an environment; this environment consists of various factors which can be categorised as internal factors, task factors and external factors. The environmental factors are dynamic in nature; they exist independently but can only function by interacting with each other. These factors are variables that should be measured when identifying job satisfaction of an academic staff.

This is briefly depicted in figure 1:

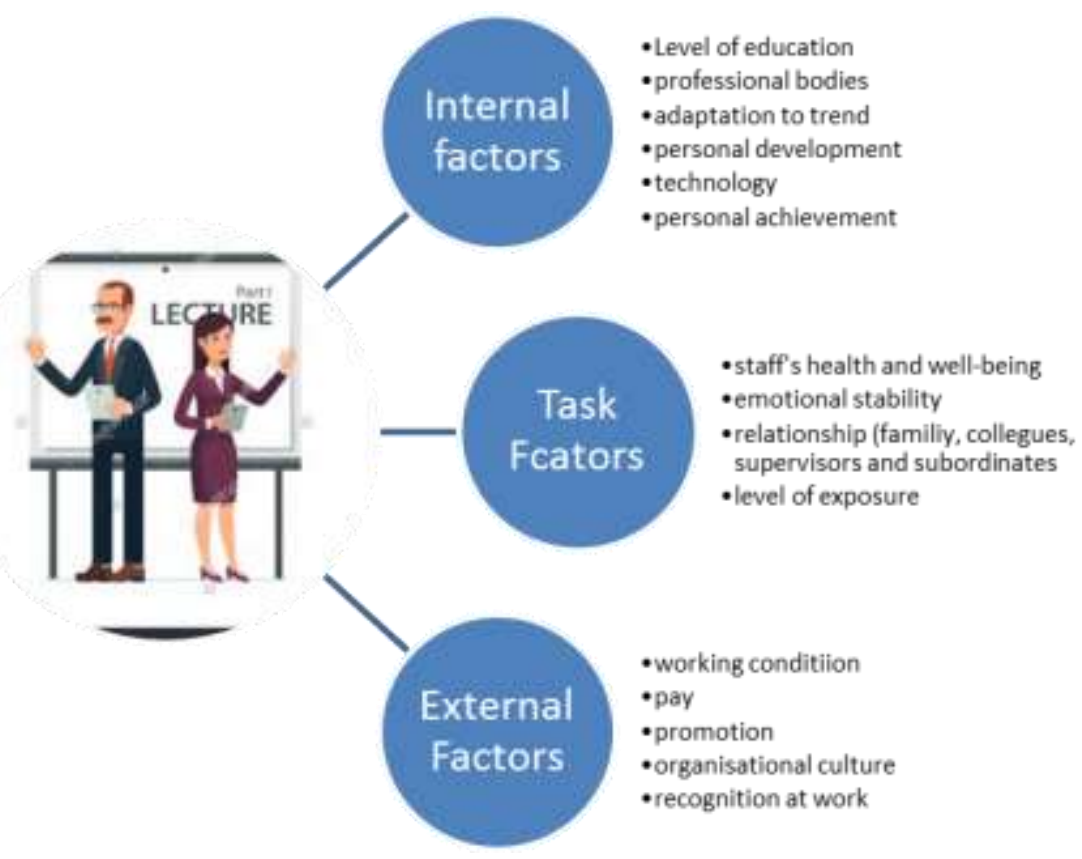

Figure 1

For this study, only external factors are considered in measuring Employee Job Satisfaction of Academic staff in Nigeria Tertiary institution. This gives room for further research.

\section{Research Design}

The study employed the survey research design. It systematically sought information from respondents on (Employee Job Satisfaction in their Universities). This survey method enabled researcher to gather respondents' opinion on current issues about research problem.

\section{Population of the study}

The population consists of Academic staff of College of Business and Social Sciences at LMU and Academic Staff of Faculty of Social Sciences at UNILORIN 


\section{Sample Size}

The sample size used in this study was 169 academic staff comprising of 32 respondents from LMU and 88 respondents from UNILORIN. Sample size was determined using Taro Yamanne formula.

Where: $\mathrm{n}=$ sample size, $\mathrm{N}=$ population, $\mathrm{e}=$ level of significance, $1=$ constant value

\section{Sampling Technique}

Population was divided into different strata and members of each stratum were selected using random sampling.

\section{Source of Data}

The primary method of data sourcing was used for this research. Data used in this study were sourced through questionnaires, which served as research instrument. Also, interviews were conducted to ensure reliability.

\section{Validity/ Reliability Test}

The validity test that was used for this research is content validity. It is an attempt to ensure that a research instrument is adequate for a study. Each item on questionnaire was reviewed in agreement with objective of study. Also, each item reviewed signifies a reasonable content and consideration was given items that were germane to the study.

The reliability of primary source was established via fact that the data consistency can be guaranteed due to its fairly permanent state that can be repeated with slight or no difference. To establish a reliable instrument, researcher used test-retest method. Questionnaires were administered to a control group after one week of initial distribution and retrieval of questionnaire.

\section{Technique for Data Analysis}

Data was analysed using descriptive statistics which consist of mean, frequency tables and percentages and standard deviation. T-test was performed to obtain differences between private and public university lecturer's level of job satisfaction.

\section{Interpretation of Results}

In conducting this research 120 questionnaires were distributed to academic staff in LMU and UNILORIN 103 was returned.

The table shows parameters used and result displayed indicate percentage of strongly agreed, agreed, not sure, disagreed, strongly disagreed.

\section{$\underline{\text { Table } 2}$}


Published by European Centre for Research Training and Development UK (www.eajournals.org)

\begin{tabular}{|c|c|c|c|c|c|c|c|c|c|c|c|}
\hline $\mathrm{S} / \mathrm{N}$ & & SA & & A & & $\mathrm{U}$ & & DA & & SD & \\
\hline $\mathrm{A}$ & PAY & $\begin{array}{l}\text { LMU } \\
\%\end{array}$ & $\begin{array}{l}\text { UNI } \\
\%\end{array}$ & $\begin{array}{l}\text { LMU } \\
\%\end{array}$ & $\begin{array}{l}\text { UNI } \\
\%\end{array}$ & $\begin{array}{l}\text { LMU } \\
\%\end{array}$ & $\begin{array}{l}\text { UNI } \\
\%\end{array}$ & $\begin{array}{l}\text { LMU } \\
\%\end{array}$ & $\begin{array}{l}\text { UNI } \\
\%\end{array}$ & $\begin{array}{l}\text { LMU } \\
\%\end{array}$ & $\begin{array}{l}\text { UNI } \\
\%\end{array}$ \\
\hline 1 & I am satisfied with my salary & & 7.9 & 48.1 & 22.4 & 7.4 & 9.2 & 37.0 & 36.8 & 7.4 & 23.7 \\
\hline 2. & $\begin{array}{l}\text { High pay increases } \\
\text { performance and efficiency }\end{array}$ & 29.6 & 22.4 & 63.0 & 48.7 & 3.7 & 9.2 & 3.7 & 11.8 & - & 7.9 \\
\hline 3 & $\begin{array}{l}\text { Remuneration paid in this } \\
\text { organization is commensurate } \\
\text { to responsibilities shouldered. }\end{array}$ & 11.1 & 9.2 & 22.2 & 15.8 & 29.6 & 21.1 & 37.0 & 35.5 & - & 18.4 \\
\hline 4 & $\begin{array}{l}\text { Fringe benefits enhances level } \\
\text { of job satisfaction }\end{array}$ & 33.3 & 39.5 & 48.1 & 35.5 & 14.8 & 13.2 & 3.7 & 5.3 & - & 6.6 \\
\hline $\mathrm{B}$ & RECOGNITION & & & & & & & & & & \\
\hline 5 & $\begin{array}{l}\text { Appreciation from } \\
\text { management increases level of } \\
\text { job satisfaction of employees }\end{array}$ & 33.3 & 31.6 & 48.1 & 46.1 & 11.1 & 6.6 & 7.4 & 5.3 & - & 10.5 \\
\hline 6 & $\begin{array}{l}\text { The organization views its } \\
\text { academic staff as assets. }\end{array}$ & 37.0 & 22.4 & 48.2 & 25.0 & 14.8 & 27.9 & - & 10.5 & - & 13.2 \\
\hline 7 & $\begin{array}{l}\text { Management recognize me as } \\
\text { an individual }\end{array}$ & 18.5 & 26.3 & 55.6 & 36.8 & 22.2 & 3.7 & 6.6 & 7.9 & - & 7.9 \\
\hline $\mathrm{C}$ & WORKING CONDITIONS & & & & & & & & & & \\
\hline 8 & $\begin{array}{l}\text { Workload reduces productivity } \\
\text { of lecturers }\end{array}$ & 51.9 & 32.9 & 37.0 & 32.9 & 3.7 & 18.4 & 7.4 & 10.5 & - & 5.3 \\
\hline 9 & $\begin{array}{l}\text { Availability of internet } \\
\text { facilities assists in better } \\
\text { service delivery }\end{array}$ & 25.9 & 50.0 & 63.0 & 27.6 & 11.1 & 14.5 & - & 2.6 & - & 5.3 \\
\hline 10 & $\begin{array}{l}\text { Sharing of offices with other } \\
\text { lecturers limits productivity of } \\
\text { lecturers }\end{array}$ & 18.5 & 29.3 & 55.6 & 32.0 & 7.4 & 24.0 & 18.5 & 10.7 & - & 4.0 \\
\hline 11 & $\begin{array}{l}\text { Conducive environment } \\
\text { encourage research }\end{array}$ & 48.1 & 55.3 & 51.9 & 35.5 & - & 5.3 & - & 3.9 & - & - \\
\hline
\end{tabular}

\section{Hypotheses and interpretation}

The hypothesis formulated was tested using t-test method. The hypothesis was tested using independent- samples T-test for hypothesis 1, 2, and 3.

Hypothesis one: There is no difference between lecturers LMU and UNILORIN in terms of pay.

UNILORIN lecturers are more satisfied in terms of pay. A comparison of lecturers in LMU and UNILORIN in terms of pay revealed that the main value of respondent perception of pay at LMU was 2.4167 with a standard deviation of 0.45993 and a standard deviation of 0.8851 . The corresponding values associated with UNILORIN lecturers were 2.8059, 0.61319 and 0.7034, for the standard deviation and standard error mean. Thus resulting in a mean difference of 0.38925 , a $\mathrm{T}$ test for significant of this mean difference, an (equal variances 
Global Journal of Human Resource Management

Vol.5, No.4, pp.33-46, May 2017

Published by European Centre for Research Training and Development UK (www.eajournals.org)

assumed) showed a calculated t-statistic of 3.008 with an associated asymptotic significant of 3.443

\section{Decision}

Ho is rejected at $1 \%$ level since computed significant probability of $0.003<$ assumed level of significant of 0.001

\section{Implication}

There is a significant difference between LMU lecturers and UNILORIN lecturers in terms of pay.

Furthermore since the mean of UNILORIN at 2.8059 > lecturers of LMU at 2.4167, we can conclude at $99 \%$ confidence level that UNILORIN lecturers are more satisfied than LMU lecturers in terms of pay.

Hypothesis two: There is no difference in recognition among lecturers in LMU and UNILORIN

A comparison of lecturers at LMU and UNILORIN on the basis of recognition among lecturers revealed that the main value of respondent perception of recognition at LMU was 2.0465 with a standard deviation of 0.36714 and a standard deviation of 0.7066 . The corresponding values associated with UNILORIN lecturers were $2.4770,0.61379$ and 0.07034, for the standard deviation and standard error mean. Thus resulting in a mean difference of 0.43068 , a $\mathrm{T}$ test for significant of this mean difference, an (equal variances assumed) showed a calculated t-statistic of 3.427 with an associated asymptotic significant of 4.317

\section{Decision}

Ho is rejected at $1 \%$ level since computed significant probability of $0.001<$ assumed level of significant of 0.000

\section{Implication}

There is a difference in recognition among the lecturers in LMU and UNILORIN.

Since the mean of UNILORIN at 2.4770 is > lecturers of 2.0463 , we can conclude at $99 \%$ confidence level that there is a difference in recognition among the lecturers in LMU and UNILORIN.

Hypothesis three: There is no relationship in the level of working conditions between the employees of LMU and UNILORIN. A comparison of the lecturers at in both Universities on the basis of working conditions revealed that the main value of respondent perception of pay at LMU was 1.8241 with a standard deviation of 0.44297 and a standard deviation of 0.08525 . The corresponding values associated with UNILORIN lecturers were 1.9833, 0.76376 and 0.08819 , for the standard deviation and standard error mean. Thus resulting in a 
mean difference of 0.15926 , a $\mathrm{T}$ test for significant of this mean difference, an (equal variances assumed) showed a calculated t-statistic of 1.021 with an associated asymptotic significant of 1.298

\section{Decision}

Ho is rejected at $1 \%$ level since the computed significant probability of $0.310<$ assumed level of significant of 0.198

\section{Implication}

There is no relationship in the level of working condition between the working condition between the employees of LMU and UNILORIN.

Furthermore since the mean of University of Ilorin at $1.8241>$ lecturers of 1.9833 , we can conclude at $99 \%$ confidence level that there is no relationship in the level of working condition between the employees of LMU and UNILORIN.

\section{FINDINGS}

The summary of the findings and observation based on data gathered via questionnaires which were administered to the lecturers of LMU and UNILORIN

The research showed that UNILORIN lecturers are more satisfied than LMU lecturers in terms of pay and promotions. After testing the hypothesis, a pay differential does exist between private and public universities in Nigeria. Lecturers in public university were more satisfied with their pay, promotions, and the lecturers of private university.

The research also shows that there is no relationship in the level of working condition between the employees of LMU and UNILORIN. Therefore management should try and reduce workload in order to enhance the productivity of lecturers and they should also try to provide a conducive environment in order to encourage research.

\section{CONCLUSION}

To conclude, findings of the study illustrate that job satisfaction improves performance of the lecturers. These findings suggest that when lecturers are satisfied with their job, they can enhance the academic potential of the students. In addition; there is a difference in job satisfaction between public and private university lecturers in job satisfaction.

The results of this study revealed that three out of four areas of job satisfaction investigated significantly affect job satisfaction of academic staff. When workers are satisfied on their job, it is expected that they will perform better. Concluding from this assumption the Universities authority should strive to make all categories of lecturers (both Junior and Senior) satisfy on their job. 


\section{RECOMMENDATIONS}

Recommendations proffered based on the findings is that any organizations that desires to promote job satisfaction among employees should improve on those job satisfaction dimensions such as pay, recognition and working condition in its workplace so as to achieve high level of organizational commitment among its employees which eventually enhances the organization effectiveness.

The study suggested that management should formulate policies regarding job satisfaction such as proper reward system or work incentives, encouraging working environment particularly in private sector, and a proper career infrastructure etc.

\section{REFERENCES}

Adeniji, A. A. (2011). Organizational Climate and Job Satisfaction Among Academic Staff in Some Selected Private Universities in Southwest Nigeria. Vasa. Retrieved from http://medcontent.metapress.com/index/A65RM03P4874243N.pdf

Ajayi, B. I. A., \& Ekundayo, H. T. (2008). The Deregulation of University Education in Nigeria : Implications for Quality Assurance . Journal of Multidisciplinary Scholarship, 5(December), 212-224. Retrieved fronobleworld.biz/nebulajmsarchives/nebula54.html

Akhtar, S. N., Hashmi, M. A., \& Naqvi, S. I. H. (2010). A comparative study of job satisfaction in public and private school teachers at secondary level. Procedia - Social and Behavioral Sciences, 2(2), 4222-4228. http://doi.org/10.1016/j.sbspro.2010.03.668

Amazt, I. H., \& Idris, A. R. (2011). Lecturers' satisfaction towards university management \& decision-making styles in Some Malaysian public universities. Procedia - Social and Behavioral Sciences, 15, 3957-3970. http://doi.org/10.1016/j.sbspro.2011.04.400

Anho, J. E. (2011). An evaluation of the quality and employability of graduates of Nigeria universities. African Journal of Social Sciences, 1(1), 179-185.

Aslan, A. S., Shaukat, M. Z., Ahmed, I., Shah, I. M., Mahfar, M., Senin, A., ... Mad, I. (2014). Job Satisfactions of Academics in Malaysian Public Universities. Procedia Social and Behavioral Sciences, 114, 154-158. http://doi.org/10.1016/j.sbspro.2013.12.676

Badmus, A. D., \& Enahoro, J. a. (2013). Emergence of Private Universities in Nigeria and Monitoring Standards between 2002 And 2012. American Journal of Business and Management, 2(1), 59-64. http://doi.org/10.11634/216796061302258

De Lourdes Machado, M., Soares, V. M., Brites, R., Ferreira, J. B., \& Gouveia, O. M. R. (2011). A look to academics job satisfaction and motivation in Portuguese higher education institutions. Procedia - Social and Behavioral Sciences, 29, 1715-1724. http://doi.org/10.1016/j.sbspro.2011.11.417

Demirtaş, Z. (2010). Teacher's job satisfaction levels. Procedia - Social and Behavioral 
Published by European Centre for Research Training and Development UK (www.eajournals.org)

Sciences, 9, 1069-1073. http://doi.org/10.1016/j.sbspro.2010.12.287

Jafar, R., Kavousian, J., Beigy, A., Emami, M., \& Hadavizadeh, A. (2010). The study of job satisfaction among Bandar Abbas Islamic Azad university staff. Procedia - Social and Behavioral Sciences, 5(2), 258-261. http://doi.org/10.1016/j.sbspro.2010.07.084

Matthew, I. A. (2013). Evolution of private universities in Nigeria: Matters arising and the way forward. Educational Research and Reviews, 8(2), 41-50. http://doi.org/10.5897/ERR11.119

Nohria, N., Groysberg, B., Lee, L. (2008). Employee motivation; A Powerful New Model. Harvar Business Review www.hbr.org

Okoro, PrisciEdwin, O. (2014). Time and Change: Development of Private Universities in Nigeria, 5(9), 186-192.

Spector, P.E. (1997). Job Satisfaction: Application, Assessment, Causes and Consequences. Thousand Oaks, CA Sage.

http://nuc.edu.ng/nigerian-univerisities/federal-univeristies/viewed 29/07/16 